outbreak of war, and in permanently removing its fundamental causes. The International Peace Campaign offers us the great opportunity of working effectively for both these ends." Stressing the importance of the radical approach, it added that scientific workers should co-operate "in the task of removing the causes of war by subjecting them to scientific and historical analyses and by exposing the theories of those who strive to excuse and justify war."

It was unanimously agreed, therefore, that a permanent Science Commission of the International Peace Campaign should be set up "with the general object of uniting all scientists in the struggle for peace". Its proposed activities include (1) the coordination of the work of the existing peace organizations of scientific workers and their extension to countries in which they do not exist ; (2) the formation of joint commissions on $(a)$ science and war and (b) the removal of the basic causes of war ; (3) propaganda for a peace oath by all scientific workers and the incorporation of such a declaration in the oaths of those taking university degrees and diplomas; (4) concrete support for those scientific workers who are made to suffer for refusing to take part in research or other activities concerned with war.

The joint commission on science and war is to include chemists, physicists, engineers, aeroplane technicians, doctors, bacteriologists, geologists and military experts, who will endeavour (1) to study the technique of modern warfare and its probable effects on the military and civil populations ; (2) to co-operate effectively in the international suppression of chemical and biological warfare; (3) to publish the results of its investigations promptly and clearly, without minimizing or exaggerating the dangers of modern war or seeking to claim an unobtainable accuracy; (4) to issue critical bibliographies on the technique of warfare and other special studies on this subject; (5) to impress on scientific workers themselves the part they are playing, directly or indirectly, in preparations for war, and to direct attention to the utilization for military purposes of funds intended for civil research and development; (6) to serve as an information bureau on technical military questions to all peace organizations.

The committee concerned with the fundamental causes of war is to include biologists, psychologists, anthropologists, medical men, sociologists, historians and economists, whose immediate task it will be to produce a concise statement on the causes of war and the ways in which men of science can help to eliminate them. It will also neglect no opportunity to expose pseudo-scientific and pseudo-historical theories used for war propaganda, such as those which postulate the biological necessity of war, the need for colonial expansion because of population pressure, the innate inequality of races, the degenerating effects of miscegenation, and so on. The regular work of this committee will therefore include (1) continuous propaganda in the scientific and popular press; (2) the exposure of subtle and direct war propaganda in schools and colleges ; (3) appeals to learned societies and other organizations to defend scientific truth against distortion and unjustified rationalization; (4) the provision of study facilities by the publication of critical bibliographies and such other assistance as a central bureau can provide.

The translation of these objectives into effective practice will require considerable funds, organizational ability and individual support, but the success of the Peace Congress as a whole, combined with other evidence of a widespread appreciation of the duty and purpose of seientific endeavour, suggests that these essentials will not be lacking. They must not be if the lust for war is to be overcome by an organized will for peace.

\title{
Molluscs of Northern Asia
}

$\mathrm{M}^{\mathrm{B}}$ R. ALAN MOZLEY, after several studies of the Mollusca of Canada, has recently made expeditions into Siberia and northern Kazakstan during the open seasons of the years 1932 and 1933, when typical areas in several of the great natural regions were examined in some detail, and extensive collections made with the object of obtaining fresh and accurate information regarding the constitution and distribution of the molluscan fauna ("The Freshwater and Terrestrial Mollusca of Northern Asia". Trans. Roy. Soc. Edin., 58, Part 3 (No. 24), 193536). The area covered includes the greater part of continental Asia to the north of latitude $50^{\circ}$, not including Outer Mongolia and Manchuria.

The aquatic species inhabit three types of waterponds, lakes and streams. Of these the ponds and pond-like lakes only have an abundant molluscan fauna, and these are mostly hardy northern European species. Both the large lakes, which are uncommon, and the streams, usually present special conditions unfavourable to the molluses. There is found to be a small group of circumboreal, a large number of Eurasian species, a few which are common to North America and north-eastern Asia, and several endemic forms. On the basis of these groups, Northern Asia may be divided into four faunal regions, the Great Siberian Region, the Baikal Region, the Far Eastern Region and the Chuckchee-Kamchatka Region.

In the northern part of Kazakstan and Southern Siberia there are numerous drainage basins in which the reservoirs are saline to a varying degree, the main salts being chlorides and sulphates which are detrimental to the molluscs. The presence of old shore lines round many of these indicates their greater extent during previous pluvial periods, fossil molluses being found in some of these old shore-line deposits, in some cases the number of species decreasing in the descending series of beaches, giving evidence of a progressive decrease in molluses. The species most tolerant of these conditions are Planorbis planorbis L., Limncea palustris saiidalensis Mozley, and Limnoea palustris Kazakensis Mozley.

Temporary ponds formed by melting snow in spring are characteristic habitats in the steppe and forest steppe region both in Canada and Siberia, conditions of life being severe; but numbers of invertebrates manage to exist in them, including five species of molluscs in Northern Asia. 